\title{
Biochemical changes associated with the use of haemodilution with $5 \%$ dextrose in water and mannitol for open-heart surgery
}

\author{
I. W. P. OBEL, P. MARCHAND, AND L. DU PLESSIS \\ From the Cardiovascular Research Unit, University of Witwatersrand, and the Department of \\ Thoracic Surgery and the Cardiac Clinic, Johannesburg General Hospital
}

\begin{abstract}
Many advantages are gained from the use of haemodilution in open-heart surgery. There is a lessened post-operative morbidity from bleeding, renal failure, and serum hepatitis. However, dilution with $5 \%$ dextrose in water is associated with a greater metabolic acidosis and a higher incidence of serious dysrhythmias than is pure blood. In order to elucidate the causes of these complications, 26 patients were studied using different degrees of haemodilution. The metabolic acidosis appeared to be mainly due to the dilution of blood buffer. Changes in electrolyte balance were more marked with greater dilution. The effects on serum sodium and chlorides were transient. The serum potassium level fell markedly during the post-operative phase and was associated with dysrhythmias. We believe that variation in potassium concentration is due to redistribution of potassium between the intracellular and extracellular phase as well as to an increased urinary excretion of potassium. The acidosis and hypokalaemia can be rapidly corrected by the administration of sodium bicarbonate and potassium. The changes in acid-base metabolism and electrolyte balance can possibly be prevented by suitably modifying the priming fluid.
\end{abstract}

The massive quantities of blood used during open-heart operations may cause complications unrelated to the actual surgery. Serum hepatitis occurs in direct proportion to the quantity of blood given; a case incidence of $0.6 \%$ per bottle of blood has been reported by Alsever and Barger (1961). Occult incompatibility reactions can occur in spite of meticulous cross matching and proved in vitro compatibility (Fudenberg and Allen, 1957 ; Allison and Blumberg, 1961). Schmidt, Peden, Brecher, and Baranovsky (1961) and Krevans, Jackson, Conley, and Hartmann (1957) have shown that with the use of pure blood primes the early disruption of platelets may cause postoperative bleeding.

Diluted blood-priming solutions were first introduced by Zuhdi, McCollough, Carey, and Greer in 1961. By 1962 Cooley, Beall, and Grondin had already gained an extensive experience of this technique which they believed reduced the complications of bypass perfusions. It is now claimed that haemodilution affords protection against renal failure (Norman, McDonald, and Sloan, 1964 ; DeWall, Lillehei, and Sellers, 1962 ; and Gadboys and Litwak, 1963) and that the urinary output in the immediate post-operative period is almost double that obtained when wholeblood primes are used (Zuhdi, Carey, Sheldon, and Greer, 1964). Haemodilution is also said to lessen the danger of sudden unexplained blood volume fluctuations which occur after cardiopulmonary bypass (Litwak, Gilson, Slonim, McCune, Kiem, and Gadboys, 1961).

Early in our experience with haemodilution perfusions we became concerned with the number of patients who were in a state of undue exhaustion after surgery and with the number who developed severe arrhythmia. As a result we embarked on a prospective study of the biochemical changes during and following bypass.

\section{METHODS}

Twenty-six patients were studied (Table I). Using DeBakey pump heads and a disc oxygenator, high flow rates $\left(2 \cdot 31 . / \mathrm{m}^{2}\right.$ to $\left.2 \cdot 51 . / \mathrm{m}^{2}\right)$ were maintained even when the mid-oesophageal temperature had dropped to $30^{\circ} \mathrm{C}$. (Marchand, Middleton, Benington, and Shreve, 1959 ; Marchand, Du Plessis, Beckerling, and Durr, 1964). Pure blood was the priming fluid in two cases and diluted blood in twenty-four. In 10 cases the dilution was one part of $5 \%$ dextrose water to three parts blood, and in 14 it was two parts of 
T A B LE I

SUMMARY OF PATHOLOGY, OPERATIVE PROCEDURE, AND HAEMODILUTION USED IN THE 26 PATIENTS STUDIED

\begin{tabular}{|c|c|c|}
\hline Diagnosis & $\left|\begin{array}{c}\text { No. of } \\
\text { Patients }\end{array}\right|$ & Operative Procedure \\
\hline 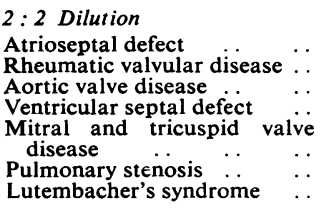 & $\begin{array}{l}1 \\
8 \\
1 \\
1 \\
1 \\
1 \\
1\end{array}$ & $\begin{array}{l}\text { Repair } \\
\text { Replacement } \\
\text { Valvotomy } \\
\text { Closure } \\
\text { Replacement and repair }{ }^{1} \\
\text { Repair } \\
\text { Repair }\end{array}$ \\
\hline Total & 14 & \\
\hline $\begin{array}{l}\text { 1:3 Dilution } \\
\text { Rheumatic valvular disease ... } \\
\text { Atrioseptal defect } \ldots \\
\text { Mitral and aortic valve disease } \\
\text { Mitral and aortic valve disease } \\
\text { Ostium primum A.S.D. } \\
\text { Obstructive cardiopathy } \quad .\end{array}$ & $\begin{array}{l}5 \\
1 \\
1 \\
1 \\
1 \\
1\end{array}$ & $\begin{array}{l}\text { Replacement } \\
\text { Closure } \\
\text { Valvuloplasty } \\
\text { Mitral valvotomy } \\
\text { Aortic valve replacement } \\
\text { Repair } \\
\text { Relief }\end{array}$ \\
\hline Total & 10 & \\
\hline $\begin{array}{l}\text { Pure Blood } \\
\text { Aortic valve disease } \ldots \\
\text { Atrioseptal defect } \quad \ldots\end{array}$ & $\begin{array}{l}1 \\
1\end{array}$ & $\begin{array}{l}\text { Replacement } \\
\text { Closure }\end{array}$ \\
\hline Total & 2 & \\
\hline
\end{tabular}

${ }^{1}$ Tricuspid valvuloplasty.
$5 \%$ dextrose water to two parts blood. Heparinized blood, less than 24 hours old, was used. The $2: 2$ dilution was used for the first 14 patients and the $1: 3$ dilution for the next ten. Mannitol, $25 \mathrm{~g}$., was added to the priming fluid because of its alleged renal protective properties (Norman et al., 1964). The anaesthetist did not purposely hyperventilate the lungs before but did so mildly after bypass.

Diuretics were stopped seven days before operation, and these patients were given $2 \mathrm{~g}$. potassium bicarbonate daily by mouth for five days. On each of the two pre-operative days patients received $4 \mathrm{~g}$. potassium chloride orally as a liquid, regardless of whether they had been on diuretics or not.

The blood urea, serum sodium, potassium, chloride, and $\mathrm{CO}_{2}$ content were measured preoperatively and every six hours post-operatively for six days, starting immediately after completion of surgery. Post-operative assessments of the degree of acidosis were made in 20 patients. Nine of these patients had 1:3 dilutions, nine had $2: 2$ dilutions, and two had pure blood primes.

The urinary potassium excretion was measured over 24 hours in five patients receiving the $2: 2$ dilution. The blood urea, serum sodium, potassium, chloride, $\mathrm{CO}_{2}$ content, and urinary urea were measured in an AutoAnalyzer and the urinary sodium and potassium by flame photometry. The oxygen-carrying capacity of the blood was measured by the method of Peters

T A B L E I I

\begin{tabular}{|c|c|c|c|c|c|c|c|c|c|c|c|c|c|c|c|c|}
\hline \multirow{3}{*}{ No. } & \multirow{3}{*}{ Age } & \multirow{3}{*}{ Sex } & \multirow{3}{*}{$\begin{array}{l}\text { Pre-op. } \\
\text { Diur- } \\
\text { etics }\end{array}$} & \multicolumn{10}{|c|}{ Electrolytes (mEq/1.) } & \multirow{3}{*}{$\begin{array}{c}p \mathrm{H} \text { as } \\
\text { NaHCO } \\
\text { Required } \\
\text { (mEq/m. }{ }^{2} \text { ) }\end{array}$} & \multirow{3}{*}{$\begin{array}{l}\text { Length } \\
\text { of } \\
\text { Bypass } \\
\text { (min.) }\end{array}$} & \multirow{3}{*}{$\begin{array}{c}\text { Urinary } \\
\text { Output } \\
\text { (ml./ } \\
1 \mathrm{st} \\
24 \mathrm{hr} \text { ) }\end{array}$} \\
\hline & & & & \multicolumn{5}{|c|}{ Pre-operative } & \multicolumn{5}{|c|}{ Post-operative } & & & \\
\hline & & & & Urea & $\mathrm{Na}$ & $\mathbf{K}$ & $\mathrm{Cl}$ & $\mathrm{CO}_{2}$ & Urea & $\mathrm{Na}$ & $\mathbf{K}$ & $\mathrm{Cl}$ & $\mathrm{CO}_{2}$ & & & \\
\hline \multicolumn{17}{|c|}{ 2:2 Dilution } \\
\hline $\begin{array}{r}1 \\
2 \\
3 \\
4 \\
5 \\
6 \\
7 \\
8 \\
9 \\
10 \\
11 \\
12 \\
13 \\
14\end{array}$ & $\begin{array}{r}15 \\
50 \\
39 \\
35 \\
53 \\
53 \\
16 \\
27 \\
27 \\
16 \\
24 \\
5 \\
4 \\
12\end{array}$ & $\begin{array}{c}\mathbf{F} \\
\mathbf{F} \\
\mathbf{F} \\
\mathbf{F} \\
\mathbf{M} \\
\mathbf{F} \\
\mathbf{M} \\
\mathbf{F} \\
\mathbf{M} \\
\mathbf{F} \\
\mathbf{M} \\
\mathbf{F} \\
\mathbf{F} \\
\mathbf{F}\end{array}$ & $\begin{array}{l}+ \\
+ \\
+\end{array}$ & $\begin{array}{l}23 \\
36 \\
31 \\
35 \\
31 \\
43 \\
31 \\
34 \\
34 \\
23 \\
55 \\
26 \\
21 \\
26\end{array}$ & $\begin{array}{l}136 \\
135 \\
131 \\
142 \\
136 \\
135 \\
139 \\
126 \\
136 \\
139 \\
138 \\
136 \\
140 \\
141\end{array}$ & $\begin{array}{l}4.4 \\
4.1 \\
4.8 \\
3.4 \\
3.7 \\
3.8 \\
5.3 \\
4.0 \\
4.7 \\
4.5 \\
4.4 \\
4.3 \\
4.3 \\
4.8\end{array}$ & $\begin{array}{r}99 \\
97 \\
96 \\
101 \\
104 \\
98 \\
98 \\
92 \\
100 \\
104 \\
100 \\
92 \\
95\end{array}$ & $\begin{array}{l}25 \\
23 \\
20 \cdot 5 \\
24 \\
21 \cdot 5 \\
24 \cdot 5 \\
24 \\
20 \\
22 \\
20 \\
22 \cdot 5 \\
28 \\
21 \\
25\end{array}$ & $\begin{array}{l}28 \\
74 \\
31 \\
45 \\
28 \\
73 \\
38 \\
32 \\
30 \\
23 \\
59 \\
31 \\
21 \\
32\end{array}$ & $\begin{array}{l}144 \\
140 \\
135 \\
138 \\
143 \\
131 \\
141 \\
131 \\
141 \\
127 \\
137 \\
133 \\
138 \\
135\end{array}$ & $\begin{array}{l}2 \cdot 9 \\
2 \cdot 4 \\
2 \cdot 9 \\
2 \cdot 4 \\
2 \cdot 6 \\
3 \cdot 3 \\
3 \cdot 1 \\
2.8 \\
3 \cdot 4 \\
3 \cdot 1 \\
2 \cdot 7 \\
2 \cdot 6 \\
2 \cdot 4 \\
3 \cdot 1\end{array}$ & $\begin{array}{r}93 \\
85 \\
91 \\
90 \\
98 \\
96 \\
94 \\
80 \\
93 \\
92 \\
116 \\
95 \\
87\end{array}$ & $\begin{array}{l}32 \cdot 5 \\
20 \cdot 4 \\
27 \\
27 \\
28 \\
22 \\
31 \cdot 5 \\
25 \cdot 5 \\
34 \cdot 5 \\
18 \\
22 \cdot 5 \\
28 \\
27 \\
26\end{array}$ & $\begin{array}{l}120 \cdot 48 \\
104 \cdot 16 \\
235 \cdot 29 \\
338 \cdot 54 \\
138 \cdot 89 \\
296 \cdot 05 \\
307 \cdot 26 \\
133 \cdot 33\end{array}$ & $\begin{array}{r}35 \\
90 \\
30 \\
95 \\
50 \\
91 \\
75 \\
60 \\
150 \\
40 \\
45 \\
18 \\
40\end{array}$ & $\begin{array}{r}1,440 \\
700 \\
550 \\
1,480 \\
625 \\
600 \\
2,110 \\
950 \\
1,300 \\
830 \\
700 \\
400 \\
700 \\
350\end{array}$ \\
\hline
\end{tabular}

1:3 Dilution

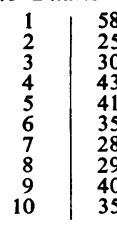

\begin{tabular}{c|c|c|c}
$\mathbf{M}$ & & 19 \\
$\mathbf{F}$ & & 30 \\
$\mathbf{F}$ & & 30 \\
$\mathbf{M}$ & & 34 & \\
$\mathbf{F}$ & + & 21 \\
$\mathbf{F}$ & + & 30 \\
$\mathbf{F}$ & + & 16 & \\
$\mathbf{M}$ & & 34 & \\
$\mathbf{F}$ & + & 47 & \\
$\mathbf{M}$ & + & 31 &
\end{tabular}

\begin{tabular}{l|r|r|l}
134 & $4 \cdot 2$ & 89 & 28 \\
147 & $4 \cdot 6$ & 97 & 14 \\
126 & $4 \cdot 9$ & 88 & 24 \\
127 & $3 \cdot 7$ & 92 & 22 \\
133 & $4 \cdot 8$ & 94 & $29 \cdot 5$ \\
141 & $4 \cdot 8$ & 104 & $24 \cdot 5$ \\
136 & $4 \cdot 5$ & 100 & 26 \\
136 & $4 \cdot 5$ & 99 & $22 \cdot 5$ \\
134 & $3 \cdot 5$ & 91 & 31 \\
143 & $4 \cdot 3$ & 102 & 30
\end{tabular}

\begin{tabular}{l|l}
36 & 138 \\
32 & 138 \\
38 & 130 \\
43 & 143 \\
22 & 147 \\
28 & 135 \\
46 & 143 \\
34 & 135 \\
36 & 137 \\
30 & 139
\end{tabular}

\begin{tabular}{|r|r|}
$2 \cdot 7$ & 91 \\
$2 \cdot 8$ & 96 \\
$3 \cdot 8$ & 98 \\
$2 \cdot 7$ & 96 \\
2.8 & 97 \\
2.6 & 93 \\
$3 \cdot 0$ & 100 \\
$3 \cdot 8$ & 97 \\
$3 \cdot 2$ & 91 \\
3.9 & 99
\end{tabular}

\begin{tabular}{l|r}
28 & \\
24 & $93 \cdot 75$ \\
23 & $156 \cdot 25$ \\
$25 \cdot 5$ & $138 \cdot 12$ \\
28 & $66 \cdot 67$ \\
$24 \cdot 5$ & $156 \cdot 25$ \\
$26 \cdot 5$ & $126 \cdot 58$ \\
25 & $58 \cdot 82$ \\
31 & $101 \cdot 35$ \\
24 & $166 \cdot 67$
\end{tabular}

\begin{tabular}{r|r}
60 & 800 \\
39 & 1,000 \\
& 50 \\
85 & 1,040 \\
122 & 1,000 \\
60 & 600 \\
35 & 1,150 \\
& 1,540 \\
45 & 1,430 \\
& 700
\end{tabular}

Pure Blood

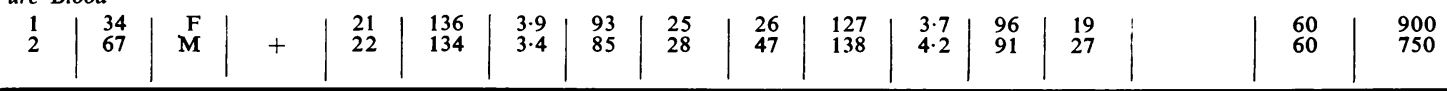


and Van Slyke (1932) and the arterial blood $p H$ and $\mathrm{PCO}_{2}$ and standard bicarbonate by the method of Siggaard Andersen, Engel, Jørgensen, and Astrup (1960). The degree of acidosis is represented as the quantity of sodium bicarbonate $\left(\mathrm{mEq} / \mathrm{m} .^{2}\right.$ body surface area) needed to return the $p \mathrm{H}$ to normal.

\section{RESULTS}

The observations of acid base and electrolyte balance are set out in detail in Table II. When changes occurred during the day of surgery, corrective measures were immediately taken, making it impossible to follow the later 'natural' course of events.

ACID BASE BALANCE There was no appreciable fall in the $p \mathrm{H}$ of the priming fluid irrespective of the degree of dilution, and no difference was found between the $p \mathrm{H}$ of the diluted and pure blood primes. Post-operatively, metabolic acidosis was encountered and there was a direct relationship between the length of bypass and the degree of acidosis (Figs 1, 2, and 3). The average duration of bypass was similar in the two groups: $71 \mathrm{~min}$. in the $1: 3$ dilution group and $63 \mathrm{~min}$. in the $2: 2$ dilution group. A direct relationship between the degree of dilution and the severity of acidosis was also apparent (Fig. 4). The group with 1:3 dilutions showed less acidosis (a mean of $118 \mathrm{mEq} \mathrm{NaHCO}_{3} / \mathrm{m}^{2}$ being required to correct the acidosis) than those with $2: 2$ dilutions (where the mean was $203 \mathrm{mEq} \mathrm{NaHCO}_{3} / \mathrm{m}^{2}$ ).

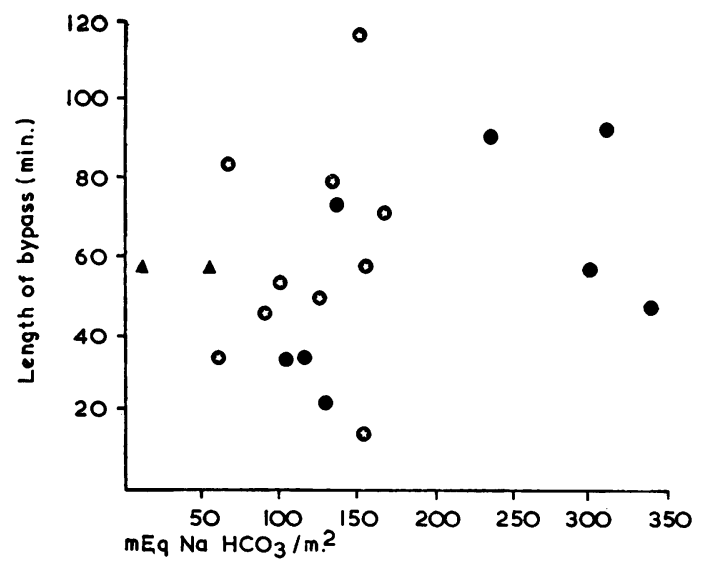

FIG. 1. Relationship of the length of bypass to the severity of acidosis in all groups. Although the acidosis increases with the length of bypass, it can be seen that the greater the dilution, the more severe the acidosis for comparable periods of bypass. Acidosis is measured in $\mathrm{mEq}$ $\mathrm{NaHCO}_{3} / \mathrm{m}^{2}$ required to restore arterial blood $\mathrm{pH}$ to normal. $2: 2$ dilution; $1: 3$ dilution; $\Delta$ no dilution.

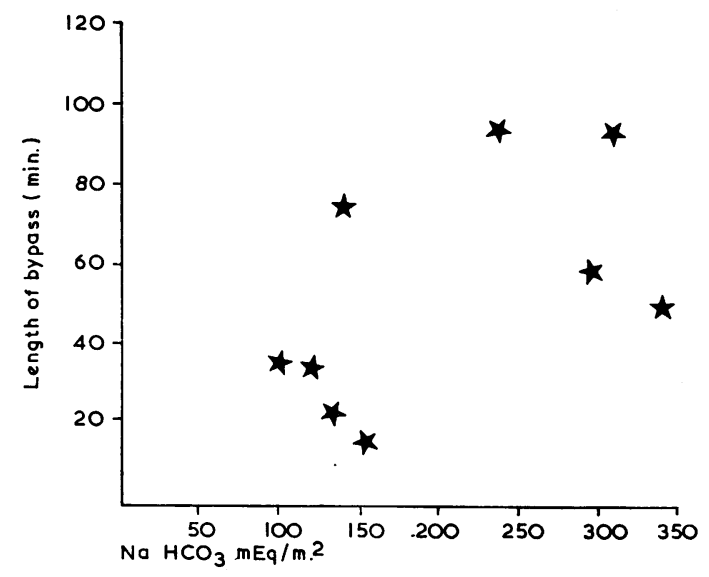

FIG. 2. Relationship of the length of bypass to the severity of acidosis in the group with $2: 2$ dilution. Increas- $\overline{\widehat{\partial}}$ ing length of bypass is associated with increasing severity of acidosis.

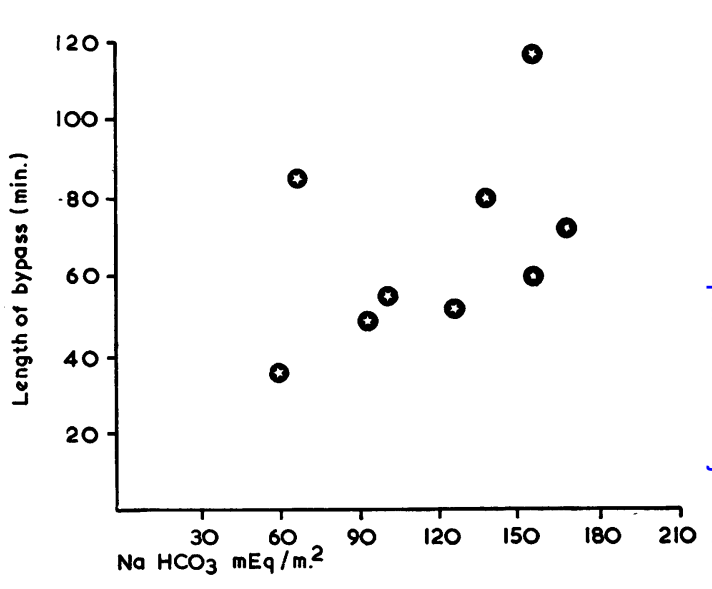

FIG. 3. Relationship of the length of bypass to the severity of acidosis in the group with $1: 3$ dilution.

OXYGEN-CARRYING CAPACITY This was only mea- 0 sured in patients with $2: 2$ dilutions, and the $\mathcal{E}$ oxygen-carrying capacity was found to be approximately $60 \%$ of that of undiluted blood $\stackrel{C}{C}$ primes.

ELECTROLYTES Major electrolyte changes were $\frac{T}{0}$ found both in the priming fluids and in the circu- $\frac{\vec{D}}{\mathrm{D}}$ lating blood of the patients during and after by- $?$ pass. The addition of dextrose water to blood $\stackrel{\AA}{\mathscr{\perp}}$ immediately lowered the concentration of allo serum electrolytes (Fig. 5; Table III). With the 8 
onset of bypass, when the patient's blood and the priming solution had mixed, the electrolyte concentrations reverted towards normal, and by the

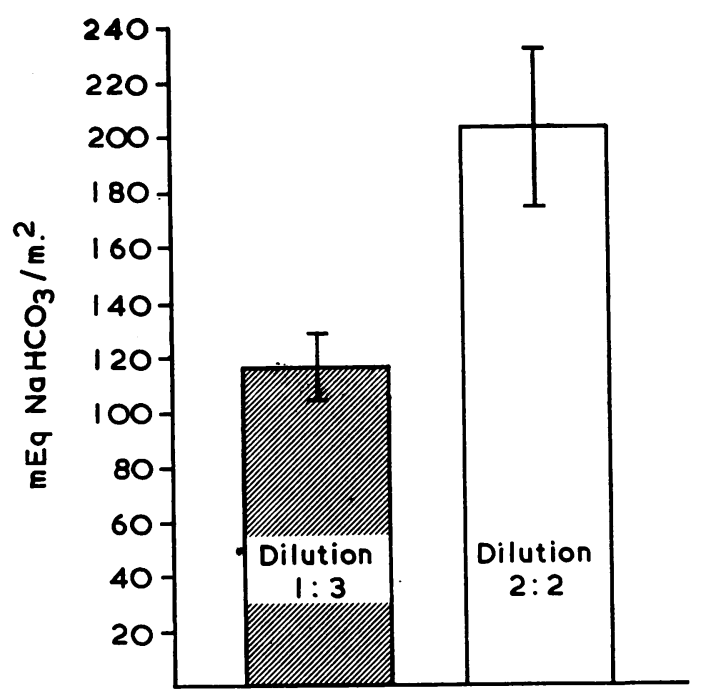

FIG. 4. Average degree of metabolic acidosis in the two groups each of nine patients with different degrees of haemodilution is compared. This is represented as the quantity of sodium bicarbonate in $\mathrm{mEq} / \mathrm{m} .^{2}$ body surface area to return the arterial $\mathrm{pH}$ to normal $(\mathrm{I}=$ standard error $)$.
T A B L E I I I

SERUM SODIUM LEVELS (mEq/l.) OF THE PRIME BLOOD BEFORE AND AFTER DILUTION WITH EQUAL PARTS OF $5 \%$ DEXTROSE IN WATER

\begin{tabular}{c|c|c|c|c}
\hline & \multicolumn{4}{|c}{ Serum Sodium (mEq/1.) } \\
\cline { 1 - 4 } & $\begin{array}{c}\text { Before } \\
\text { Dilution }\end{array}$ & $\begin{array}{c}\text { After } \\
\text { Dilution (D) }\end{array}$ & $\begin{array}{c}\text { Expected } \\
\text { Level (E) }\end{array}$ & $\begin{array}{c}\text { Difference } \\
\text { (D-E) }\end{array}$ \\
\hline & 133 & 100 & 53.6 & 46.4 \\
& 136 & 70 & 37.8 & 32.2 \\
& 139 & 100 & 56 & 44.0 \\
& 126 & 100 & 50.7 & 49.3 \\
Mean & 130 & 90 & 52.4 & 37.6 \\
\hline & 132.8 & 92.0 & 50.1 & 41.9 \\
\hline
\end{tabular}

end of bypass no major electrolyte disturbance usually remained (Fig. 5). Exceptions were long bypasses of one and a half hours or more. In some of these the serum potassium dropped towards the end of the perfusion, though never lower than $3.3 \mathrm{mEq} /$ litre. Immediately after bypass ended and after the body temperature had been restored the serum electrolytes were normal, with the exception of potassium, which often dropped precipitously during the first hour. The fall in serum potassium concentration occurred in every case where haemodilution was employed, dropping from a mean level of $4.3 \mathrm{mEq} / 1$. preoperatively to a mean of $2.9 \mathrm{mEq} / 1$. postoperatively (Fig. 6). This fall of $1.4 \mathrm{mEq} / 1$. is statistically highly significant $(P<0.01)$. The

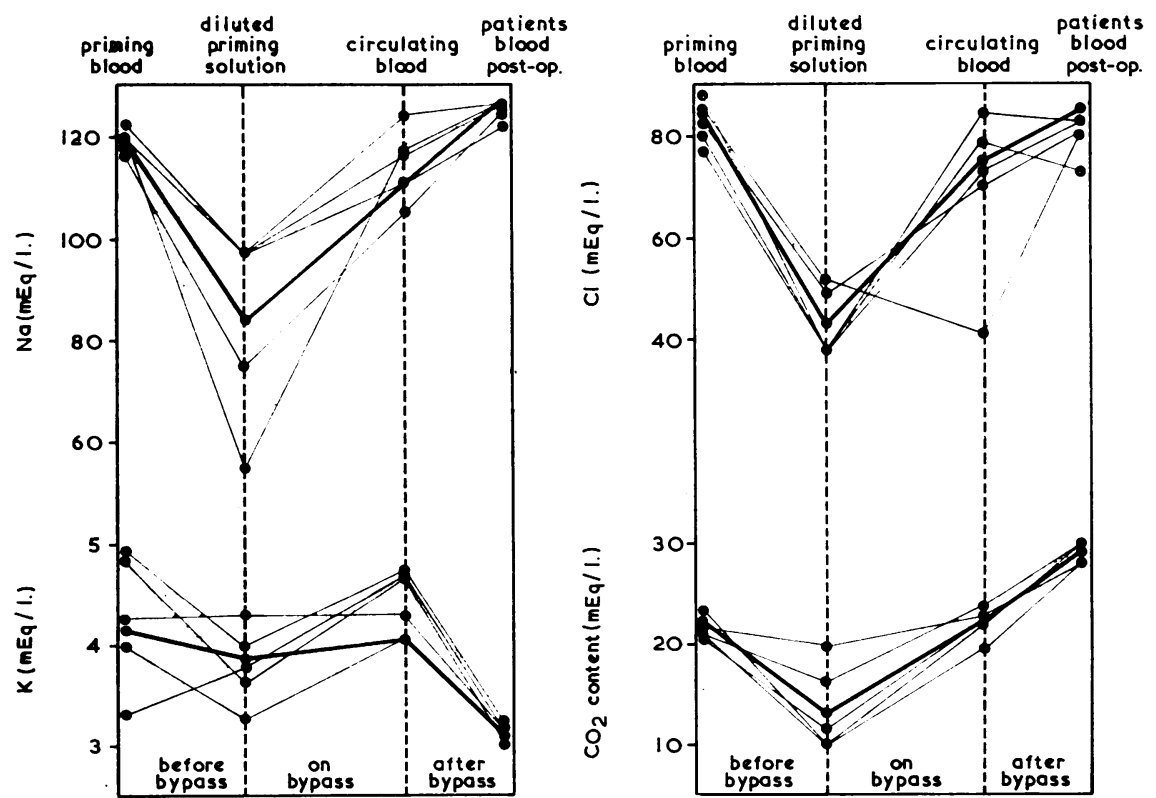

FIG. 5. Serum electrolyte changes of the priming fluid before and after dilution and of the circulating blood during and after bypass in five patients. 
extent of the post-operative fall was related to the degree of dilution but not necessarily to the length of bypass: it was most pronounced in the group with the 2:2 dilution (Fig. 6) ; only a slight fall occurred in the patients with pure blood primes $(0.04 \mathrm{mEq} / 1$.).

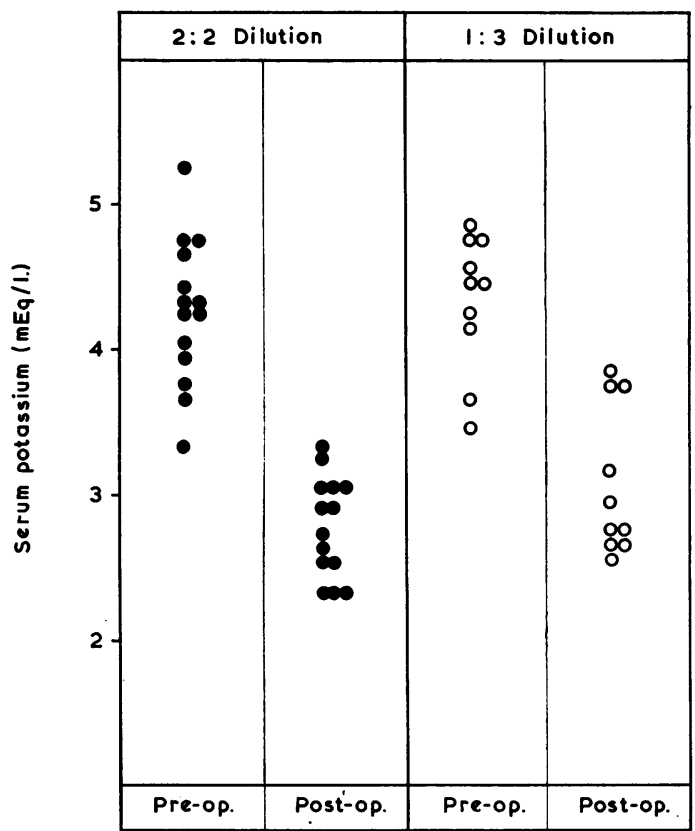

FIG. 6. Changes in the serum potassium levels before and after operation.

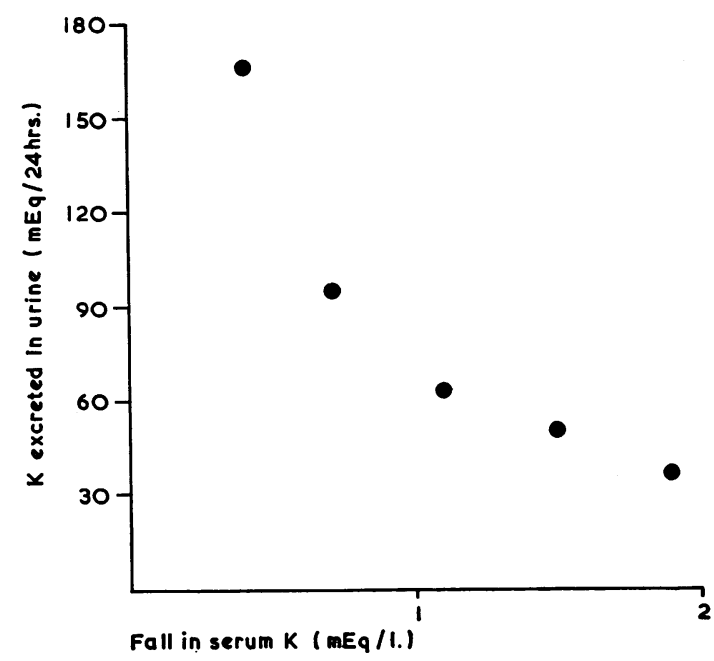

FIG. 7. Urinary loss of potassium on the day of surgery compared with the fall in $\mathrm{mEq}$ from the pre-operative levels.

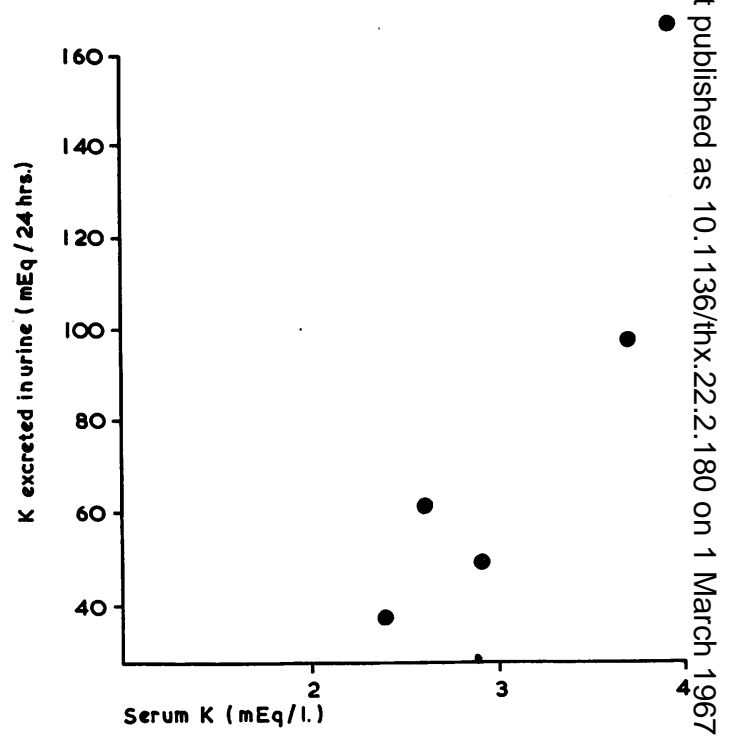

FIG. 8. Urinary potassium loss compared with the post operative serum potassium levels in five patients. The high urinary loss of potassium even in the presence of low serums levels is demonstrated.

Excessive amounts of urinary potassium were excreted during the first 24 hours after surgery응 This was measured in five patients and the loss was found to vary from 38 to $164 \mathrm{mEq}$ during the 24 hours (Figs 7 and 8).

\section{DISCUSSION}

McCaughan and Lee (1964), Mackenzie, Davies? Masson, and Wade (1963), and Kolff, Effler, and Groves (1960) have all stressed the danger of metabolic acidosis during and after cardioo pulmonary bypass. Metabolic acidosis is probably due to many different causes. The $p H$ of the $5 \%$ dextrose water supplied to us during the three month period of this investigation ranged betweerp 4.0 and 4.5 . Nevertheless, the $p H$ of the diluted priming blood before bypass was normal in alt patients; this must have been achieved at the expense of the stored blood buffer. With perfusion the patient's blood buffer is also diluted by the dextrose and water prime (Schlosser and Grotes 1964) and this dilution may be further enhanced by the entry of water into the extracellular come partment from the cell. Movement of water fron the cell is consequent upon the osmotic effect of hyperglycaemia. Under conditions of hypothermia sugar metabolism is impaired, perpetuating the 
hyperglycaemia and so increasing the plasma osmolality (Wright and Gann, 1963), an effect which is further enhanced by the use of mannitol.

The effect of dilution of blood buffer is in part to decrease the concentrations, particularly of circulating bicarbonate, whilst $\mathrm{CO}_{2}$ continues to be produced (Winters, Scaglione, Nahas, and Verosky, 1964). DeWall et al. (1962) have mentioned the possibility that the dextrose may result in an excess production of lactate, thus increasing the acidosis. Dilution of haemoglobin favours the production of acidosis ; first, because haemoglobin is an important blood buffer, and, secondly, because dilution of haemoglobin is associated with a decreased oxygen-carrying capacity of the blood. According to Mackenzie et al. (1963) the diminished oxygen-carrying capacity may result in hypoxia and consequent acidosis. Arteriovenous oxygen differences during dilution perfusions have been found to be normal, however (Roe, 1963), so this factor is probably not important.

In our experience, acidosis is more pronounced with dilute than with pure blood primes. Acidosis rises progressively with increasing dilution: with the same or even shorter periods on bypass, patients with $2: 2$ primes suffered more acidosis than those with $1: 3$ primes (Figs 1 and 4). These observations do not agree with the findings of McCaughan and Lee (1964). Mackenzie and his co-workers (1963) feel that hyperventilation may cause metabolic acidosis by increasing the bicarbonate loss in the urine. However, we never found that an alkaline blood $p \mathrm{H}$ preceded the onset of acidosis. Moreover, acidosis and hypokalaemia occurred simultaneously, so that the hypokalaemia cannot be attributed to either metabolic or respiratory alkalosis.

The initial dilution of the serum electrolytes of the priming blood was corrected by the end of bypass, usually soon after bypass began. The later $\mathrm{CO}_{2}$ changes were affected by the therapeutic steps which were taken to combat acidosis, and cannot therefore be accurately interpreted. The fall of serum sodium in the priming fluid was less than would be expected to result from simple dilution (Table III). The expected fall can be calculated from the dilution of plasma sodium by taking into account the haematocrit of the blood before and after dilution. The difference between the expected and the observed levels indicates that sodium had moved from an intracellular to an extracellular phase. Neither clinical nor biochemical hyponatraemia occurred post-operatively. The fact that there is only a slight fall of the serum potassium in the diluted priming blood is also explicable on the basis of movement of potassium from the red cells into the plasma.

The changes of serum potassium had important post-operative clinical effects. Cardiac arrhythmias were common and one patient died suddenly from ventricular fibrillation on the second day when her serum potassium was $2.8 \mathrm{mEq} /$ litre. A second patient, with low serum potassium, developed ventricular fibrillation on return to the ward. She was resuscitated by countershock and there was no recurrence of arrhythmia following the administration of intravenous potassium chloride. In three patients, after valve replacement (two not included in this series), repeated attempts at electrical defibrillation while still on bypass were ineffective until potassium was given. This suggests that the serum potassium was abnormally low, as does the fact that the fibrillating hearts were hypertonic and contracted; unfortunately, blood samples were not taken. An increased incidence of ventricular fibrillation with haemodilution has been observed by McCaughan and Lee (1964).

All patients with low serum potassium levels developed ventricular extrasystoles which were often multifocal and multiple. The extrasystoles were most severe when the serum potassium level was lowest ; they responded to the administration of potassium and virtually disappeared when the serum potassium was restored to normal. In our opinion, arrhythmia induced by hypokalaemia is the most important complication of haemodilution (Obel, Marchand, and Du Plessis, 1965). Extrasystoles often presage more serious arrhythmias, particularly ectopic ventricular tachyarrhythmias. All the patients in this study had received digitalis. It is therefore possible that hypopotassaemia produced digitalis intoxication with consequent rhythm disturbance, as described by Lown, Wyatt, Crocker, Goodale, and Levine, in 1953, but it is known that hypopotassaemia alone may cause arrhythmia (Young, Sealy, and Harris, 1954).

Early in our experience with haemodilution we noticed that, post-operatively, patients who were unusually listless and atonic responded to the administration of potassium. One patient developed a myasthenia-like state with bilateral external ophthalmoplegia which recovered after potassium administration. Working with dogs, Kahn, Hidalgo, Steude, Ericsson, Lee, and Sloan (1963) observed that the greater the degree of haemodilution the more lethargic was the animal on recovery. Zudhi and co-workers (1964) found 
that neurological complications are more common after dextrose-water priming than after pure blood perfusions.

Low levels of serum potassium could result from excessive urinary excretion, from movement of the ion into the cell, or from both. The urinary excretion of potassium during the first postoperative 24 hours has been compared with the fall in serum potassium in five patients, and no positive correlation emerges (Fig. 7). This is expressed in another way in Fig. 8, where the measured post-operative serum potassium is compared with the 24-hour urinary potassium excretion on the day of operation. High potassium excretions occurred even when the serum level was low. In two patients the urinary loss was as high as 160 and $100 \mathrm{mEq} / \mathrm{l}$. in 24 hours. De Wardener (1961) has stated that with a serum potassium of less than $3.0 \mathrm{mEq} / 1$. the excretion of more than $20 \mathrm{mEq}$ of potassium in the urine over 24 hours indicates a renal leak. On this basis a renal leak of potassium is shown in all five patients in whom urinary loss of potassium was measured. These randomly selected patients had previously normal serum potassium levels, and the renal leak must have been acutely acquired and related to bypass. However, this degree of urinary potassium loss over 24 hours cannot account for the total fall in serum potassium. To account for the excessive fall, potassium must also move from an extracellular to an intracellular phase. It has been suggested by DeWall et al. (1962) that this accompanies the movement into the cell of glucose derived from the priming fluid. The fall in serum potassium usually corresponds with the restoration of normal body temperature and the resumed normal glucose metabolism. Presumably the potassium content of the renal tubular cell similarly increases and the urinary leak of potassium is due to its high intracellular concentration in the renal tubular cells as described experimentally by Flemma and Young (1964). Barnard, Saunders, Eales, and Barnard (1966) have stated that postbypass hypokalaemia is probably due to alkalosis ; we feel, however, that this is unlikely to be the sole cause but may contribute to or unmask abnormal potassium dynamics.

DeWall et al. (1962) and Paton, Rosenkrantz, and Blount (1964) have observed a fall in potassium after haemodilution perfusions. Paton et al. consider the fall to be insignificant, whilst DeWall et al. have noted a drop from $3 \cdot 4$ to $3 \cdot 1$ $\mathrm{mEq} /$ litre. We often leave mixed blood in the machine after bypass, whereas these authors routinely return all the fluid to the patient. This cannot be the only explanation for our different results, because the delayed and marked drop in serum potassium has occurred even when the $\frac{\bar{\sigma}}{\bar{c}}$ entire contents of the machine have been returned $\vec{\sigma}$ to the patients.

We wish to thank Dr. B. Goldberg and Dr. J. B. $\vec{\circ}$ Barlow for the very considerable help they have given us during this investigation and in the preparation of $\vec{\omega}$ this paper.

The Cardiovascular Research Unit is supported by $\underset{\vec{x}}{\vec{*}}$ grants from the C.S.I.R. (S.A.), the Johannesburg City Council, and the Wellcome Foundation. We are $N$ grateful to the organizations for their continued support.

\section{REFERENCES}

Allison, A. C., and Blumberg, B. S. (1961). An isoprecipitation reaction distinguishing human serum-protein types. Lancet, 1, 634. Alsever, J. B., and Barger, J. D. (1961). Thymol turbidity and thymol flocculation tests as a screening technic to detect blood donors carrying the hepatitis virus. II. The results of follow up studies? of 6 months or more on 2,385 transfused patients. Transfusion (Philad.), 1, 295.

Barnard, M. S., Saunders, S. J., Eales, L., and Barnard, C. N. (1966). డి Hypokalaemia during extracorporeal circulation. Lancet, 1, 240.

Cooley, D. A., Beall, A. C., Jr., and Grondin, P. (1962). Open-heart operations with disposable oxygenators, $5 \%$ dextrose prime and normothermia. Surgery, 52, 713.

DeWall, R. A., Lillehei, R. C., and Sellers, R. D. (1962). Hemodilution perfusions for open-heart surgery. New Engl. J. Med., 266, 1078.

De Wardener, H. (1961). The Kidney, p. 58, 2nd ed. Churchill, London. 으

Flemma, R. J., and Young, W. G., Jr. (1964). The metabolic effects of 2 mechanical ventilation and respiratory alkalosis in postoperative $\rightarrow$ patients. Surgery, 56, 36.

Fudenberg, H., and Allen, F. H. (1957). Transfusion reactions in the absence of demonstrable incompatibility. New Engl. J. Med., 256, 1180 .

Gadboys, H. L., and Litwak, R. S. (1963). The postperfusion hema-O tocrit. $J$. cardiovasc. thorac. Surg., 46, 772.

Kahn, D. R., Hidalgo, H. F., Steude, G. M., Ericsson, J. A., Lee, $\overrightarrow{\vec{\partial}}$ R. W. S., and Sloan, H.'(1963). Hemodilution studies in extra-O corporeal circulation with the use of a rotating-disc oxygenator. Ibid., 46, 765.

Kolff, W. J., Effler, D. B., and Groves, L. K. (1960). A review of the four dreaded complications of open-heart operations. Causes 3 avoidance, and treatment of acidosis, overoxygenation, heart block and pulmonary damage. Brit. med. J., 1, 1149.

Krevans, J. R., Jackson, D. P., Conley, C. L., and Hartmann, R. C. (1957). The nature of the hemorrhagic disorder accompanying hemolytic transfusion reactions in man. Blood, 12, 834.

Litwak, R. S., Gilson, A. J., Slonim, R., McCune, C. C., Kiem, I., and Gadboys, H. L. (1961). Alterations in blood volume during 'normovolemic' total body perfusion. J. thorac. cardiovasc.으.
Surg., 42, 477.

Lown, B., Wyatt, N. F., Crocker, A. T., Goodale, W. T., and Levine, $\bar{N}$ S. A. (1953). Interrelationship of digitalis and potassium in $\sigma$
auricular tachycardia with block. Amer. Heart J., 45, 589.

Mackenzie, G. J., Davies, S. H., Masson, A. H. B., and Wade, J. D. S (1963). Causes of metabolic acidosis in extracorporeal circulation N at normothermia. Thorax, 18, 215.

McCaughan, J. J., Jr., and Lee, W. H., Jr. (1964). Hemodilution with deep hypothermia and circulatory stasis. Circulation, 29, Suppl. [Cardiovascular Surgery 1963], p. 67.

Marchand, P., Middleton, E. J., Benington, C. W., and Shreve, I. P. (1959). On equipping a heart-lung unit. Med. Proc., 5, 409.(E) Du Plessis, L., Beckerling, C., and Durr, M. H. (1964). Extra-corporeal hypothermia without thoracotomy. Brit. J. Surg., 51, 305 .

Norman, J. C., McDonald, H. P., and Sloan, H. (1964). The early $\frac{O}{(\mathbb{D}}$ and aggressive treatment of acute renal failure following cardio- $(\mathbb{D}$ pulmonary bypass with continuous peritoneal dialysis. Surgery,
$\mathbf{5 6}, 240$.

Obel, I. W. P., Marchand, P., and Du Plessis, L. A. (1965). The biochemical effects of dextrose and water priming of the pump for open-heart surgery. $S$. Afr. med. J., 39, 309. 
Paton, B. C., Rosenkrantz, J. G., and Blount, S. G. (1964). Clinica and physiological results of perfusion with diluted blood. Circulation, 29, Suppl. 1, p. 63.

Peters, J. P., and Van Slyke, D. D. (1932). Ouantitative Clinical Chemistry. Vol. 2, Methods, Chapter 30. Williams and Wilkins, Baltimore (1956).

Roe, B. B. (1963). Discussion on a paper by Kahn and others. $J$. thorac. cardiovasc. Surg., 46, No. 6, 781 .

Schlosser, V., and Grote, G. (1964). Blood gases and acid-base metabolism with the use of blood and blood substitutes in artificial circulation during hypothermia. Surgery, 55, 440.

Schmidt, P. J., Peden, J. C., Jr., Brecher, G., and Baranovsky, A. (1961). Thrombocytopenia and bleeding tendency after extracorporeal circulation. New Engl. J. Med., 265, 1181.

Siggaard Andersen, D., Engel, K., Jørgensen, K., and Astrup, P. (1960). A micro method for the determination of $\mathrm{pH}, \mathrm{CO}$ tension, base excess and standard bicarbonate in capillary blood. Scand. J. clin. Lab. Invest., 12, 172.
Winters, R. W., Scaglione, P. R., Nahas, G. G., and Verosky, M. (1964). The mechanism of acidosis produced by hyperosmotic infusions. J. clin. Invest., 43, 647.

Wright, H. K., and Gann, D. S. (1963). Hyperglycemic hyponatremia in nondiabetic patients. Arch. intern. Med., 112, 344.

Young, W. G., Jr., Sealy, W. C., and Harris, J. S. (1954). The role of intracellular and extracellular electrolytes in the cardiac arrhythintracellular and extracellular electrolytes in the cardiac arrhyth636.

Zuhdi, N., Carey, J., Sheldon, W., and Greer, A. (1964). Ccmparative merits of results of primes of blocd and $5 \%$ dextrose in water for heart-lung machines: Analysis of 250 patients. $J$. thorac. cardiovasc. Surg., 47, 66 .

- McCollough, B., Carey, J., and Greer, A. (1961). Double-helical reservoir heart-lung machine, designed for hypothermic perfusion; primed with $5 \%$ dextrose in water; inducing he modilution. Arch. Surg., 82, 320. 